\title{
MOTIVATION FOR STUDYING AND GENDER ISSUE
}

\author{
VIDACEK-HAINS V.; DivJaK, B. \& OSTROSKI, M.
}

Abstract: The primary goal of this research was to examine the motivation for studying and the reasons for choosing specific higher education institutions which provide a curricula in the area of Information and Communication Technology (ICT) and Entrepreneurship in Croatia. The second goal of this research was to test the gender differences in the factor structure of motives for choosing certain types of study. Results show that the social factors, the possibility of employment, the quality of curricula and the general advantages of professional development were crucial for selecting this particular faculty. A similar motivation structure was identified in both male and female students. The goal oriented motivation style is dominant with students of both genders whereas the learning and relationship oriented styles are less represented. The results can be used to adjust courses and teaching methods to cater for the needs of individual students.

Key words: motivation, motivation style, gender, factor analyses
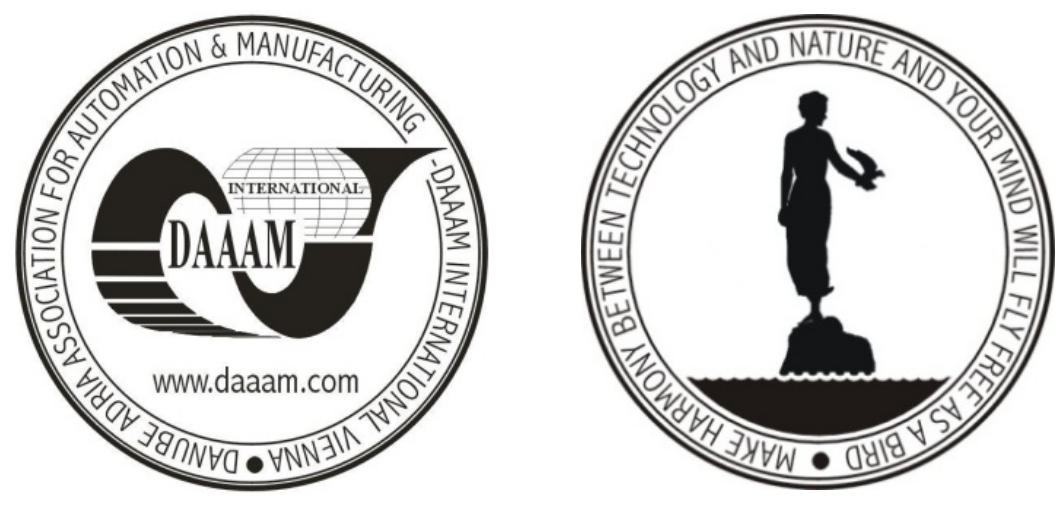

Authors' data: Dr. sc. Vidacek-Hains, V[ioleta]; Univ.Prof.Dr.Sc. Divjak, $\mathrm{B}$ [lazenka]; Ostroski, M[irela], University of Zagreb, Faculty of Organization and Informatics, Pavlinska 2, 42 000, Varazdin, Croatia, vvidacek@foi.hr, bdivjak@foi.hr, mostroski@foi.hr

This Publication has to be referred as: Vidacek-Hains, V[ioleta]; Divjak, B[lazenka] \& Ostroski, M[irela] (2009). Motivation for Studying and Gender Issue, Chapter 22 in DAAAM International Scientific Book 2009, pp. 197-208, B. Katalinic (Ed.), Published by DAAAM International, ISBN 978-3-901509-69-8, ISSN 17269687, Vienna, Austria

DOI: $10.2507 /$ daaam.scibook.2009.22 